\title{
DISCERNING THE SPIRITS OF MODERNITY AND POSTMODERNTY
}

\author{
by David Nikkel
}

This article originally appeared in Tradition \& Discovery: the Polanyi Society Periodical, 2006-07, v. 33:1

I count myself among a large number of scholars of religion (and other

disciplines) who believe that we live in the midst of a major shift in Western culture-

that we are moving from the modern age into a postmodern age. ${ }^{1}$ In the opening sections

of this essay I will delineate some distinguishing characteristics of the postmodern versus

the modern spirit. I will proceed by describing respective controlling assumptions and concomitants of first modernity, then postmodernity. One postmodern assumption is that every individual and culture has basic assumptions, models, images, pictures that control the way one views the world. Such controlling assumptions function like eyeglassesone looks with or through them, but does not normally look at them. (And indeed some assumptions are so basic or prereflective that, like one’s own eye, one cannot look at them at all.) $)^{2}$ Next I will discuss historical and logical relationships between the modern and postmodern spirits.

Postmodern sensibility would caution against any absolute postulating of the essence of an era, especially in contrast to another era. So I offer my understanding of the modern versus postmodern spirit not as an absolute or monolithic schema that disallows countervailing tendencies or alternative schemas, but as a general description of some contrasting tendencies involved in this cultural shift. Adding to this general caveat my judgment that the movement from modernity to postmodernity has been long and gradual, I expect astute readers will have no problem identifying exceptions to my distinctions. 
In the final sections of the essay, I will consider the relationship of the postmodern spirit to theology, primarily through the use of selected and hopefully representative movements and figures. In light of the judgment that the move to postmodernity has been a protracted one, I will look at some trends in theology, from Schleiermacher to the contemporary scene, in terms of their affinity with the postmodern spirit. Finally, I will examine three types of self-descriptively postmodern theology and assess them in relation to the spirit or logic of postmodernity as I have construed it. While I intend this construal to be acceptable to all three camps—-the radical or deconstructionist/poststructuralist, the conservative or "postliberal," and the moderate, an important purpose of this essay is to take a stand for moderate postmodernism. So I write as a critical and constructive theologian of the moderate postmodern strand, contending that it alone among the types consistently draws out the implications of the postmodern spirit—while the other two end up being more modern than postmodern in crucial respects. This project thus counters the use of "postmodern" as a synonym for “deconstructionist" or "poststructuralist” by some scholars, both sympathetic and unsympathetic to radical postmodernism. My attempt to define "postmodern" is thus an enactment of the postmodern insight that reality is (in part) defined, enacted by us.

\section{The Modern Spirit}

An original hallmark of modernity has been its stress on the individual and its great faith in individual critical reason. ${ }^{3}$ Religiously speaking, Martin Luther’s standing 
alone before the Diet of Worms dramatically signaled the coming of modernity. While the Protestant Reformation elevated the authority of Scripture, individual critical reason and conscience—hopefully guided by the Holy Spirit—received new freedom to interpret Scripture and make judgments. Correspondingly, this development greatly diminished the collective authority of institutions and tradition.

Certain Renaissance paintings represent the artistic beginnings of modernity as they reveal a controlling assumption or "picture" of modernity (Poteat, 59). In contrast to actual vision, everything in these paintings, including all elements of the foreground and background, appears crystal clear. A basic assumption of modernity is that the individual can leave behind all limitations of one's body and perceptual equipment, temporality, language, and culture and reach an absolutely privileged position where one can "see" everything (including oneself) with complete clarity. Descartes, controlled by this picture, signaled the beginning of modern philosophy. Finding that all of his knowledge failed according to such a criterion of absolute—and explicitable—certainty, Descartes finally felt he reached the privileged position in his reflexive and self-conscious subjectivity_- I think, therefore I am.” In comparison with the Reformation, the ensuing Enlightenment of course radicalized the role of critical reason with respect to Scripture and tradition. ${ }^{4}$

I will now consider some ramifications of this controlling picture of modernity, mostly confining my remarks to the realm of Western thought ${ }^{5}$ :

1) Probably the most significant consequence of modernity's picture of the absolutely lucid and self-possessed subject was its dualisms between subject and object, mind and matter, including the body. If the individual human subject or mind is the 
absolutely privileged starting point, it becomes difficult or impossible to reach or have any meaningful connection with the object or the physical (especially by the criterion of absolute certainty). The question becomes, how can mind impose meaning on inherently meaningless matter? For the flip side of the absolute subject is the absolute object: critical, distancing reason tends to turn what is in its gaze into nothing but an object. If, conversely, the simply material object and sense perception that supposedly mirrors the object serve as the absolutely privileged starting point, then it becomes difficult or impossible to reach or find any meaningful role for the human subject—which tends to be reduced to simply an aggregate of matter and energy. As with Humpty Dumpty, no one could put subject and object back together again, given the controlling assumption of modernity.

In either its idealist or physicalist manifestations, modernity's controlling picture leads to loss of meaning and, in the extreme, to personal and cultural insanity: idealism by sundering us from our bodies and emotions and our embodiment in the world; physicalism by having no place for the sacredness of human and animal life. While physicalism emphasizes the body as physical system, it is as discarnating as idealism, alienating us from our experiential, intentional bodies. Idealism divorces purpose from the world; physicalism divorces the world from any purpose.

2) Having (assumedly) left behind the nitty-gritty of existence in time, modern thinkers have been wont to claim to see the essence of being, human nature, history, the Bible, or Christianity. Such claims have often involved the positing of absolute categories, often paralleling the fundamental subject-object and mind-matter dualisms, often hierarchical. Examples include the human world versus nature, inner versus outer, 
reason versus emotion or sense perception, an enlightened age versus past benighted ages.

3) In principle, everything could come under the gaze of the absolute subject; everything should be assimilable to the individual's critical knowledge. What critical reason's categories and logic could not assimilate tended to be ignored, dismissed, or destroyed. Diverse images that come to mind include Thomas Jefferson's version of the New Testament with all supernaturalistic passages deleted, the humanities attempting to establish their relevancy before the bar of science, and the unparalleled ideological violence (at least in scale) of the modern age.

4) The model of the absolutely privileged and neutral position assumes all objects of knowledge as already fully constituted apart from the individual's coming to know. Truth is simply correspondence to a reality already "out there” (for those on the object side of the dualism) or already "in here” (for those favoring the subject side). ${ }^{6}$

\section{The Postmodern Spirit}

The contrasting controlling picture of postmodernity is a person standing in the world, with always at least “one foot in” one’s body, temporality, society, culture, language, history, tradition, etc. While humans do indeed have reflexive, critical, transcending capabilities (far greater than those of any other animals on earth), such capabilities are not absolute as modernity tended to assume. One's ability to take off the eyeglasses through which one looks at reality and to look at those eyeglasses is limited. One cannot get out of one's own skin! One implication of the postmodern controlling assumption is that a person always stands embodied, enmeshed, enculturated in meaning 
and value. Normally we do not need critical reason to establish or justify meaning a la Descartes and his successors. Rather, critical reason can come into play when questions arise in our practice or when meanings break down.

Following are ramifications of postmodernity's controlling assumption paralleling and contrasting with those of modernity:

1) Neither subject nor object constitutes the privileged starting point for postmodernity. In terms of individual epistemology—granting an inalienable social component-someone knowing or perceiving something is the only starting point. Any attempt to completely "get behind" the act of knowing, to reach the subject "in itself" (that is, in total distinction from any object known) and likewise to reach the object in itself (that is, in total distinctness from any subject knowing it), is rejected. The postmodern spirit disowns this attempt not just because of its practical impossibility, but as misguided in principle: there is no absolute or pure subject to abstract out of the world and society in which one is embodied. It regards a person as a mindbodily continuum or whole. "Mind," as our awareness of and our attempt to make sense of things, and "body," as that with which we relate to a natural and social world, are radically interrelated, and both come into play at some level in all our acts.

2) In similar fashion, postmodernity views related distinctions or polarities—such as inner versus outer, reflective versus prereflective, the human versus the natural world, linguistic versus prelinguistic —as continuous, interrelated, and relative to context (never absolutely distinguishable). Besides eschewing dualisms, the postmodern spirit also runs counter to attempts to find the (necessary) essence of being, human nature, history, a religion, or a text. In general, it distrusts any rigid or absolutistic scheme of classification 
or categorization, on the grounds that such totalizing endeavors miss the richness, complexity, and contextuality of life, especially in its temporal and changing character and it its prereflective and tacit dimensions.

3) Compared to modernity's overemphasis on the individual, postmodernity elevates the value of what transcends the individual. Descriptively and prescriptively, the cruciality of the social dimensions of life, including the authority of the group and tradition, are (or should be) recognized.

For the postmodern spirit, what appears different from or other than one's self, beliefs, or values should not ultimately be either assimilated or dismissed or reduced to a mere object. Instead one should encounter-an encounter that partially defines oneselfor engage in dialogue with the other, dialogue that appreciates and respects real differences (without entailing that one must ultimately equally accredit all the differing beliefs and values). In postmodern logic no privileged or neutral position exists to which contrary views must summarily reconcile or else face elimination.

4) The postmodern spirit holds that our perceiving, knowing, and acting play a significant role in creating the world we experience. On a very pre-reflective level, the truth of this contention becomes evident by imagining how different a lake looks to a bird flying over it or to a fish swimming in it than to a human being. Each creature's perspective brings what is there into definition—-there is no fully determinate lake in itself nor any perspectiveless perspective on the lake. ${ }^{7}$ (A la Heisenberg’s uncertainty principle, our "measuring” or perceiving always has some effect on what we know—our knowing always leaves some trace!) On a more reflective level, the vast array of 
languages, cultures, worldviews, and religions across the globe and through the ages suggests humanity's vital role in creating the worlds of meaning in which we dwell.

\section{Discerning the Spirits}

Some have characterized modernity as an era (increasingly) aware of the historical and cultural conditionedness of everything human, an era that diminished or vanquished absolutisms (e.g., Wall, Hopper). Can we square that characterization with my claim that the picture of the absolutely privileged subject controlled modernity? While modernity's critical reason slew the authoritarianisms and absolutisms of the past, it tended to do so with an assumption of its own absolutely privileged position! The ideas and values of a growing number of individuals and cultures were exposed as historically relative, but modern thinkers tended less to sense the conditioned nature of their own critical reflection. Marx and Hegel saw the relativity of all past periods of history, but nonetheless constructed an absolute master plan and final period of history. Freud discovered the falsity of the model of total and explicit human consciousness and selfcontrol, yet he used his general awareness of the subconscious realm to devise absolutistic explanations of such things as women's nature and the origin of religion.

Premodern absolutisms were uncritical and relatively prereflective. The absolute authority and rightness of a tradition or a way of life were (again relatively speaking) simply assumed. They represent a first-order naivete. Modern absolutisms were/are reflective. Supposedly neutral critical reason arrives at them. They represent a secondorder naivete. The naivete of critical reason is like a child who learns a new skill, such as 
riding a bicycle, and is so giddy with the newfound power and possibilities that the limitations of this capability, like all things human, escape notice.

Realizing or assuming the unavoidably incarnate, finite, temporally and culturally conditioned nature of even one's own thinking and valuing constitutes the crucial notion for admission into the postmodern age. To say that the postmodern spirit can be “realized” or "assumed” allows its appropriation to be either relatively reflective or relatively prereflective. Thus, the postmodern spirit overcomes or circumvents the second-order naivete of modernity.

Describing the relationships between the modern and postmodern spirits as I have above implies the inappropriateness of selecting one circumscribed period as the time Western culture left modernity and entered postmodernity. By the nineteenth century intellectuals arose who were "postmodern” in certain aspects of their thought, including Soren Kierkegaard and William James. As art had "announced” the beginnings of modernity, so also of postmodernity. Impressionist renderings of the same scene at different times of day pointed to the inescapability of temporality and perspectivalism. Cezanne’s “out of focus” paintings suggested the necessary human component in bringing our world into definition (Poteat, 59). We have been gradually entering the postmodern age and continue to do so. The combination of the modern spirit slaying many authoritarianisms and a growing postmodern spirit has I judge been influential in an overall (if uneven) trend of the lessening of absolutism and a growing tolerance for diverse viewpoints in Western culture.

Parenthetically, I will mention an ambiguity pertaining to the postmodern truth of the embodied and conditioned nature of everything human. On the one hand, this truth 
contains a summons to self-criticism-it has a critical side. It is sometimes both possible and appropriate to look at our individual and (sub)cultural eyeglasses and consider whether our lenses need a correction. In this enterprise, those wearing different spectacles can help us to see assumptions we ourselves miss. Also, the postmodern spirit calls us to guard against absolutizing our own perspective (or assuming we do not have one, which is tantamount to absolutism). On the other hand, the inescapability of our embodiment and enculturation has an acritical or precritical side: it is often inappropriate or impossible to look at our eyeglasses. Michael Polanyi noted the acritical nature of all tacit acts of knowing (PK, 264). We can only devote a limited portion of time to the reflective enterprise of making explicit the normally tacit or prereflective- the rest of the time we must live. And any such reflective attempts can only partly succeed, for critical reflection entails some temporal and perspectival distancing and separation. Finally, as indicated earlier, some assumptions are so basic that one cannot get behind them—-they are more like one's eye than like eyeglasses. ${ }^{8}$

\section{The Postmodern Spirit and Modern Theologies}

If postmodern sensibilities already emerged in the nineteenth century, they manifested themselves more strongly in Protestant theology than in most other areas of Western thought. The modern spirit had unceremoniously dethroned theology as "queen of the sciences.” Theology's past pronouncements on scientific and other "secular" matters were clearly recognized as historically limited. While theology’s competence or worth was under challenge with respect to more narrowly "religious” spheres, the cultural conditionedness of its religious formulations had not been as clearly established. 
Friedrich Schleiermacher, anticipating the further reach of critical reason, made a rather remarkable and rather postmodern acknowledgment: all of our characterizations of "the Absolute" are linguistically, culturally, and historically conditioned. With some justification this "father of modern theology" might also be called the "father of postmodern theology.”

However, Schleiermacher could not let go of one area of absolute privilege, one absolute human connection with the divine: the allegedly universal human "feeling of absolute dependence." (Note that the issue here is not the absoluteness of the divine, but the absoluteness of the claimed human connection.) Granted attempts to express this feeling are always conditioned. Granted, too, this feeling manifests itself only in and through the particular contingencies of each moment of experience. Nevertheless, as a necessary component of every human experience rather that just a potentiality that some people realize some of the time, this feeling heralds its unconditioned and absolute character. Moreover, that the particularities of this moment of experience versus that one finally do not make any difference—-we have the basic sense of our absolute dependence regardless, in that sense this feeling remains unconditioned and pure in relation to any linguistic and historical particularities.

Most nineteenth and twentieth century theology followed Schleiermacher in clinging to one absolutely privileged divine connection. For Tillich, it was the "mystical a priori"; for Whiteheadian process theology, awareness of the "initial aim" for each occasion; for neo-Thomism, implicit awareness and love for God; for existentialist theology, the courage to live authentically despite existential anxiety. Note the prereflective nature of all these connections. Modern theology had abandoned the 
attempt at an absolute reflective knowledge of God. But there remained the attempt to get underneath all cultural conditions through the prereflective.

Karl Barth, of course, denied any absolute or other connection coming from the human side. Instead, the absolute connection comes from God's intentional revelation in Jesus Christ. As with Schleiermacher, human attempts to express this connection are relative (and Barth would add prone to idolatry). But this human connection (albeit provided by God) receives absolute privilege.

I will now give general consideration to some movements in twentieth century thought which, though in some aspects very much imbued with the modern spirit, evidence important postmodern elements and implications. Existentialist philosophy and theology in good postmodern fashion attacked modern and earlier attempts to abstract out and reify an atemporal human essence. Existentialism also found earlier categorizations of reality too abstract and out of touch with the temporal and historical character of existence. Much of existentialism, though, turned only outward in postmodern critique, not recognizing the historical limitedness and tendencies to absolutism of its own definitions of human nature and categorizations of reality. For example, human beings in many contexts do not feel "thrown" into the world, but rather feel quite at home in it. On a related note, our normal embodiment and enculturation in some meaning belies the notion that one could or should always explicitly decide to take on authentic meaning. (My faulting of this aspect of existentialism does not deny the fiduciary and interpretative elements of personal commitment in all knowing and valuing.) In different ways, therefore, existentialism tended to shortchange both the self-critical and the precritical 
aspects of the postmodern spirit. In one aspect most of existentialism remained under the sway of the modern spirit: its pronounced individualism.

In contrast to existentialism, process philosophy and theology is postmodern in its focus on, and consistently positive evaluation of, the social nature and interconnectedness of reality. Its emphasis on the temporality of all existence (which it shares with existentialism) and its denial of anything concrete about the self that is unchanging through time also resonate with the postmodern. On the "down side," its Whiteheadian metaphysical system seems firmly entrenched in the rationalist or idealist branch of modernity, arising out of a desire to please the (absolute) thinking subject with its allencompassing neatness. Idealism animates its theory that "occasions of experience" comprise all reality, with matter in effect only apparent, as our abstracting from numerous low-grade (subatomic) experiences. Idealism also imbues its theory of causation, in which all causation is a matter of experience, prehension, or sympathetic feeling. To be fair, Whitehead does write of prehension in "the mode of causal efficacy"-we cannot help but to take account of what enters into our experience from the past. Yet the metaphorical reliance on experience and on our taking in or grasping what affects us does not adequately account for materiality and exteriority, that is, causal efficacy that happens quite apart from any type of awareness or desire. ${ }^{9}$

Even as modern theologians subscribed to the notion that their work was relative to their era, they generally did not notice its relativity to their identity as Western European and North American middle and upper class white males-they typically assumed they spoke for the whole of culture of their era. As suggested earlier, postmodernity's recognition of the difficulty of looking at the embodied, historical, and 
subcultural perspective with which we view reality entails that often those from another perspective can look at our "eyeglasses” better than we can. Liberation theology has certainly performed this service for mainline theology, showing how it has traditionally ignored or subsumed the otherness of persons of color, women, gays, lesbians, or the underclass and ignored or complied with their oppression. Theology should value the other voices of homosexuals, women, blacks and the Third World to fulfill the postmodern spirit's call to mutually engage the other.

\section{The Postmodern Spirit and Postmodern Theologies}

Theologies consciously or self-descriptively postmodern have tended to fall into radical, moderate, and conservative camps over the past generation. I now take up the (perhaps presumptuous) task of evaluating the contributions and prospects of those three types in light of the postmodern spirit as I have construed it - a postmodern scorecard, if you will. ${ }^{10}$ The thinkers who inform this typology are mostly North Americans in the Christian tradition (though the radicals would generally characterize themselves as influenced by, rather than part of, that tradition).

\section{A. The Radicals}

The postmodern theology that has caused the biggest splash, or the most waves, is the radical branch—deconstruction and other forms of poststructuralism. ${ }^{11}$ As a tool, it performs a valuable postmodern function in critiquing or “deconstructing”-exposing the assumptions and contradictions attending - the absolute and self-contained subject, absolute text, or absolutely privileged place in or beyond time. As an a/ontology, poststructuralism is more problematic. 
This type of theology has been labeled "severe" or "negative” (Beardslee) or “eliminative” postmodernism because it purportedly eliminates concepts of God, self, history, and truth (Griffin). The late Jacques Derrida is the premier philosophical influence behind this branch. Representatives of this type of theology in the Protestant tradition were Mark C. Taylor and the late Charles Winquist; D.G. Leahy and John Caputo offer versions in the Catholic tradition (though in Leahy's case more rooted in American pragmatism than in French postructuralism). Though Taylor has since moved beyond his deconstructive phase, I judge that he most consistently developed the implications of Derrida's philosophy for theology (especially before Derrida himself began to write about religion). Therefore, I will be in conversation with him more than any other poststructuralist theologian.

Poststructuralism arises from a problem or “crisis of representation” growing out of modernity's controlling picture—which assumed that we could transcend to reality "in itself," a reality which our perceptions or words merely represent or to which they merely correspond, but in no way constitute. The postmodern spirit, of course, senses that interest, desire, perception, interpretation, commitment, personal and communal history influence every experience. Deconstruction reacts radically against modernity's picture of transcendence and interprets postmodern insight to entail the total immanence of a person in one's experiences: We are trapped in our perceptions, our words, our interpretations, our constructions of reality—and there is nothing else (except perhaps the "nothingness" of utterly unpresentable differance). Because of its reliance on linguistic metaphors, some have falsely accused deconstruction of denying non-linguistic elements of experience. ${ }^{12}$ What deconstructionists have maintained is the heavy influence of 
language on most human experience (a position which other postmodernists would accept). The key point here, though, is that no reality exists beyond our constitution of experience through language, perception, etc.

As with the modern and general postmodern spirits, art heralded deconstructive postmodernism, through much so-called "modernist" visual art and literature. While William Beardslee may be correct in his generalization that aesthetic modernism did not, unlike deconstruction, abandon the quest for "a vision of the whole" (64, 149), I believe that the related observations of Stephen Moore and Karl Raschke are more to the point: Modernism did tend to downplay or abandon the attempt at representation or realism.

To be totally immanent in one's representations is, in Derrida's words, to plunge into "the horizontality of a pure surface" (1978:298). For deconstructionists everything is surface, appearance, horizontality. Not only do they deny absolute transcendence, but even relative height or depth. This conflicts with Polanyi’s insight that knowing involves levels where tacit components contribute to wider, deeper, or higher focal contexts of meaning. Critical reason or reflective distance takes a penultimate role in deconstructing particular contexts of meaning, but from an ultimate perspective (although deconstruction’s “a/theistic” premises disallow such a perspective) human beings are trapped in the largest context of meaning, a (predetermined?) humanly undecidable, flowing whole. ${ }^{13}$ Everything is as it ought to be, leaving no room for sin or guilt (Taylor, 1984:121, 151-58, 166-69).

In keeping with the postmodern spirit, deconstruction emphasizes the relativity of meaning to context, the connectedness of the elements within a context, and the openness of a context to further and future interconnections. This openness implies the 
inexhaustibility of reality. Ironically, though, by placing everything on the same level of “appearance," deconstruction instead offers a one-dimensional, flat, exhausted reality, lacking any sense of mystery. Similarly, deconstruction undermines its valuing of otherness and difference by reducing all alterity to distances between points on the same plane—or as components of an enclosed, fragmented self. This is one of the ironies of radical postmodernism its advocates have overlooked.

In the first place then, deconstruction holds that we are immanent and incarnated, totally inscribed in our bodies, culture, contexts of meaning. Forgoing explanation of how we can transcend our interpretations enough to come to such a second-order conclusion, deconstruction's next move is this: since only interpretation or appearance exists, and given diverse, competing, and even apparently contradictory interpretations, one cannot seriously commit to any one interpretation. Indeed, the microcosm of the self and its meanings is so fragmented that it mirrors the inconsistencies and incoherencies of the macrocosm. Hence deconstruction's sharp relativistic turn to irony or playfulness. Herein lies the supreme internal irony of radical postmodernism: the human being is regarded as totally embodied, immanent, committed, interested and at the same time called to be totally discarnate and disinterested. If per impossible, one could fully take to heart deconstruction's anthropology, schizophrenia would result. Deconstruction’s freedom from commitment to particular values or worldview can never work in practice; deconstructionists like all creatures are standing somewhere. (One commitment driving many radical postmodernists is opposition to totalizing ideologies that pretend to speak for the interests of all.) 
In a radical appropriation of the postmodern rejection of modernity's search for absolute truth, Taylor offers wandering or "erring” as the primary metaphor for the human quest for meaning (esp. 1984:13, 149-58,179). This accords with deconstruction’s belief that we can only reach the "sign” but never the destination. Given the postmodern insight that we humans can never possess absolute presence or truth, deconstruction's claim that each moment of experience involves the interplay of the presence and absence of meaning is correct. From my Christian and my personal perspective, though, even granting these two equal billing in a polar relationship errs: the presence of meaning is more basic and stronger in normal human and animal experience. ${ }^{14}$ However, deconstruction goes further and gives pride of place to the pole of absence. Its vocabulary and metaphors—such as erring, trace, shiftiness, undecidability, appearance(s) (and disappearance), marginality, darkness—suggest the insecure, unsettled, insubstantial, abysmal, and deconstructing nature of all meaning. Given the postmodern recognition of the impossibility of absolute self-presence, truth, and value, one might note that the cup of meaning is either relatively empty or relatively full. Why does deconstruction opt for (relative) emptiness? Perhaps pessimistic or skeptical personalities of its proponents play a part in deconstruction's temperament. Undoubtedly, deconstruction's emphasis on absence is partly rhetorical, an effort to counter-balance modernity’s (and the Western Greek-rooted philosophical-theological tradition's) emphasis on absolute self-possession and truth. But the decisive factor, as I have implied, now claim, and later will argue is the hidden yet controlling spirit of modernity and its haunting standard of absolute truth. 
With its emphasis on the absence of meaning, deconstruction takes its standing nowhere in ironic relativism to at least the brink of nihilism. Having radically undermined all particular meanings, deconstruction can avoid the standing nowhere of nihilism only by trying to stand everywhere—by unqualifiedly affirming the interconnected totality of all that has or will transpire (Taylor, 1984:151-58, 166-69, 182)—which is tantamount to standing nowhere relative to competing and contrasting possibilities, interpretations, and choices for individuals and societies. Practically speaking, such a universal attachment to every particular is no more possible than the ironic detachment that constitutes the flip side of the same coin.

Deconstruction's primary images for humanity and divinity cohere: Even as the person is wholly immanent in one's body and experiences, so divinity is wholly immanent with respect to the world. Taylor writes of "the ever-never-changing-same [that] is the eternally recurring play of the divine milieu in which all things [emphasis his] arise and pass away.” (1984:112-20, 183). Leahy also expresses the radical postmodernist vision: "As never before the divine flows absolutely. In this flow every notion of self is completely dissolved.” (1989:786). In this conception of divinity, more radical than most historical forms of pantheism, no place remains for transcendence, personality, or purposive agency ontologically prior to the world (Taylor, 1984:118). Deconstruction takes "the death of God"-meaning the denial of any divine transcendence or selfhood— - to be concomitant with the absence of any absolute human meaning. Here deconstruction "errs" in a sense different than Taylor's, in assuming that the contextual relativity of all human existence and meaning contravenes the existence of an Absolute Reality. ${ }^{15}$ The absence of any absolute human connection to the Absolute 
does follow from a consistent upholding of the contextuality of all human meaning; but the acknowledgement of human contextuality does not at all settle whether the Absolute exists and can be known—relatively, of course. Without denying deconstruction's claim that the traditional understanding of God reinforced modernity's picture of the absolute human subject, one can regard God as having a perfect knowledge and self-possession impossible for human beings (without entailing impassibility or immutability).

The great historical irony of deconstruction, which often denigrates "seriousness," is that it has taken modernity's controlling picture far too seriously. Its extreme reaction against that picture of neutral and absolute truth—its affirmation of total immanence with its implications of relativism—-forms the mirror image or the underside of the coin of modernity. Radical postmodernism's pessimism regarding meaning is quite appropriate relative to modernity's standard of absolute presence and meaning that must be critically established, but quite inappropriate in light of postmodernity's assumption of our inalienable embodiment and enculturation in some meaning. An absolutistic reflective move — the positing of total immanence in divergent meanings—-permits the reversal of postmodern optimism about our embodiment in meaning. In spite of this pessimism, Peter Hodgson discerns an irony stemming from the obsession with absolute presence: deconstruction ends with a "total 'having' of divinity, and an undialectical immediacy," with God as "totally incarnate in worldly inscription." (37). While on one level the radicals strenuously denounce modernity's quest for the place of absolute privilege, on a deeper (or perhaps better, more shallow) level—in the human possession of the highest possible meaning of an experience, the "surface" meaning, which is also the possession 
of totally immanent divinity, and in the unqualified affirmation of the totality of experiences - the absolutistic spirit of modernity reigns.

To be fair to Derrida and his legacy, we must finally consider his later writings that explicitly deal with religion. In particular, some writings develop a concept of messianism—endorsed and expounded upon by John Caputo—but a messianism “without content and without identifiable messiah” (Derrida, 1994:28). While Derrida grants that this messianic concept perforce comes from the particularities of tradition(s), it is intentionally a formal concept, a wholly other that challenges in the name of justice the privileged claims of any historical social structure or meaning. These latter works reveal both the ethical intent of radical postmodernism to undermine absolutistic regimes and its insufficient ontological base on which to do so. Here Derrida comes to sense the absolutistic dangers of immanentism (as Taylor explicitly did [1991]). But in doing so he posits a third companion on the transcendent side of the binary, to go with ironic detachment and unpresentable differance. Just as with the other two, we lack any direction for deciding on the justness of concrete structures and meanings.

Descartes in his exercise in radical doubt at the philosophic beginning of modernity failed to recognize his inevitable standing in the world and in meaning. Even as those controlled by the modern picture believe (falsely) that they stand nowhere in the world, so radical postmodernism, in its refusal to go beyond either a version of transcendental relativism or an unqualified affirmation of the whole, refuses to (claim a) stand in the world. Taylor wrote, "Though always enacted over a bottomless abyss, 
festive play is never grave” (1984:164). If my preceding analysis is correct, rather than dancing over the abyss of meaning, radical postmodernism is mourning at the coffin of modernity.

\section{B. The Conservatives}

Both Protestant and Catholic postliberal theologians emphasize the importance of enculturation in a tradition or worldview. The Protestants regard secularists as ensconced in a competing tradition or worldview, while the Catholics tend to view them as traditionless, homeless, and needing to return to (the authority of) the Church. Protestant postliberals include George Lindbeck, Stanley Hauerwas, and the late John Howard Yoder, with John Milbank and others adding a "Radical Orthodox" twist. The former Joseph Cardinal Ratzinger, now Pope Benedict XVI, former Lutheran Richard John Neuhaus, and George William Rutler advocate Catholic postliberalism. The Protestant postliberals engage in sophisticated postmodern discourse while the Catholics' postmodernism largely confines itself to critique of modernity for its individualism, materialism, and utilitarianism.

My following remarks on postliberal anthropology apply more directly to the Protestants who have explicitly engaged in this postmodern argumentation. The conservative postmoderns join the radicals in emphasizing human immanence in our experiences and viewpoints (though implicitly or explicitly parting company on whether a reality exists beyond our interpretations, especially in regard to ultimate reality). Noting both the deep rooting of persons in differing cultural-linguistic frameworks and the absence of a privileged position from which to adjudicate such differences, these thinkers have concluded that genuine understanding between basic perspectives is 
unlikely or impossible. Different worldviews must either contradict each other ordrawing (or misdrawing, I believe) on Wittgenstein’s concept of different “language games” for different contexts—bypass each other. Even apparent similarities and commonalities between Christianity and other cultural-linguistic frameworks allegedly prove discordant when viewed within their differing contexts. In terms of the basic assumption or picture of postmodernity, such thinkers do not see human beings as getting even one foot out of one's society, culture, history, or tradition. The critical side of the postmodern spirit is downplayed or absent. Such a conclusion also violates the postmodern spirit's respect for otherness: The other poses either a threat or an irrelevancy. ${ }^{16}$

Such tribalistic thinking allows postliberal theologians to believe that the Bible or Christianity is its own world (view) in need of no authentication or corroboration by critical reason or any non-Christian perspective. The posture of this conservative wing of postmodernity is defensive; the concern is to save Christianity from further critical attacks by modernity. Postmodern logic implies that Christianity or any worldview carries (and to some extent creates) its own self-authenticating context of meaning. However, it does not imply denying or downplaying the importance of corroboration and questioning by critical reason and by alternative perspectives. As Adam and Eve could not return to the garden of innocence, so as we leave modernity's second-order naivete about critical reason, we cannot return to the uncritical first order naivete of premodern orthodoxy. We will be the poorer in added misunderstanding and conflict and foregone cooperation if each worldview and religion naively assumes its absoluteness—absolute here in the sense of an entity unto itself, unrelated to others. In addition, this notion of a 
more or less unbridgeable gap between differing worldviews has very negative implications for a traditional Christian concern—evangelism.

Postliberals do offer a positive contribution to contemporary theology by challenging Christians to be genuinely immanent in their tradition, to recognize and claim what is meaningful in Christianity, and by increasing awareness of how Christians allow other viewpoints to define us. (An irony appears here. The postliberal belief in the incommensurability of worldviews arises in tandem with a fear of Christianity's corruption by secularism, yet postliberals fail to recognize the implausibility or impossibility of such contamination to the extent of the truth of incommensurability.) Though in considerable tension with belief in incommensurability, postliberalism does provide hope for the evangelistic efficacy of a community whose authority lies in the attractiveness of its praxis. (By contrast evangelistic hope for Catholic postliberals rests on the prospect that people in want of a moral and religious authority will return to the Church.)

Having provided Christianity intellectual sanction through the postmodern notion of culture or worldview as self-authenticating context of meaning, conservative postmodern theology then refuses to play by the logic of the notion, by the rules of the postmodern game. Christianity escapes the application of the relativity and contextuality at the heart of this postmodern idea. On what basis? On an absolutistic assumption in the modern or pre-modern spirit: that religious truth entails that God intentionally and infallibly (though acting through cultural-linguistic realities) constitutes a religion as the religion. At most one religion correctly claims to know an extra-cultural-linguistic and ultimate reality. Publicly speaking, in the short term we cannot adjudicate these 
competing claims of religious traditions, in keeping with the postliberal immanentist assumption. In the long term, the one true religion established by God will survive, while other worldviews may not. Postliberals recognize that Christianity appears as relative as any other religion to outsiders. But privately speaking, the Christian can know this Godgiven absolute connection. Clearly this theology will not settle for Christianity as one context of meaning among many-it must be the absolute religion, the one grand exception. In the tradition of Barth (whether or not Barth is cited), though this theology acknowledges the relativity of everything human on one level, ultimately God overrides human epistemological finitude.

Given the strong Polanyian influence on this project, I will address the thought of Esther Meek, who has authored an excellent book on Polanyi’s epistemology. Postliberals and the Radical Orthodox do not assume the violation or superceding of natural processes in the unique authority of the Bible. By contrast Meek in evangelical tradition does hold to supernatural interventionism to guarantee the historicity of the biblical witness. On several interconnected fronts I find Meek’s stance on revelation and biblical authority problematic from a Polanyian perspective. Historical biblical criticism constitutes a well-established tradition supported by general evidence that pre-modern people judge truthfulness by mytho-poetic, theological, and existential rather than modern historical standards as well as particular evidence that many biblical narratives are in fact not historical. In the face of such direct challenge one cannot retreat to an uncritical haven. The cruciality of science for Polanyi compounds the difficulties inherent in Meek's position, and not only in the breaking or supercession of scientific laws that grounds her view of religious authority. While an intuitive, unspecifiable, and 
tacit dimension underlies all science, scientific knowledge often defies common sense or naïve realism. Likewise we need to recognize an unscientific naivete of ancient “common sense” concerning the "historical” (see PK, 267). In the tradition of liberal Protestantism (and Judaism) we need to distinguish between theological/ethical and historical truth, as Polanyi himself suggested by endorsing "modern theology('s)" acceptance of historical biblical criticism "as its guide for reinterpreting and consolidating the Christian faith in a truer form.” (PK, 282-83). Only then can we do justice to the "universal intent" of faithful scientific and historical investigation.

While radical postmodernism images humanity and divinity consistently—total immanence prevails, conservative postmodernism downplays human transcendence and freedom, while stressing them with respect to God. God chooses to reveal God's self within one particular tradition. Personal particularity wins out over a wider, more consistently immanent revelation—a revelation consonant with both human and divine universal intent and with indeterminate future manifestations. ${ }^{17}$

\section{The Moderates}

Not being aware of a representative movement or figure that has spelled out the relevant characteristics of moderate postmodernism, I now presume to write constructively from that perspective. The moderate wing takes to heart the postmodern freedom from the modern burden of explicating and justifying all basic assumptions and all meanings. It enjoys the postmodern assurance that Christianity has meaning for those incarnated and enculturated in it. This assurance frees it to use critical reason appropriately to address problems and opportunities that arise. It alone of the three postmodern camps can be genuinely hopeful. Part of its relative optimism stems from it 
alone fully disowning absolutism. It avoids the deconstructive emphasis on the extreme tenuousness or absence of meaning relative to a hidden standard of absolute truth. It also averts postliberalism's impossible burden of maintaining or proving to the Christian community its religion's absoluteness.

I have delineated how both the radicals and the conservatives bounce back and forth between immanentist relativism and respective absolutisms. Moderate postmodernism attempts to chart a course between relativism and absolutism. For it, the absence of an absolute beginning and end does not entail deconstruction's “erring” or "aimlessness.” Rather, humans and animals in their bodily becoming in the world normally find purpose and direction in a multiplicity of goals and meanings, some more immediate or short-term, some long-term or overarching, some more definite or particular, some more provisional or general. Despite foreclosure from any absolute perspective, creatures normally come to perceptual, kinesthetic, and cognitive closure, contrary to deconstructive "undecidability."

To the extent poststructuralists would acknowledge the above description of normal experience, they might still contend that upon radical reflection (in the modern spirit, I would add) ironic skepticism is a more appropriate attitude. But moderates realize that lack of meaning and skepticism are parasitical upon meaning, upon standing somewhere. In normal experience we realize we are in touch with some truth and value, even though upon reflection or further experience we discover that we erred in some (perhaps crucial) respect or missed the greatest possible value (and, indeed, perhaps caused horrible evil in the process). 
Crucially moderates realize and claim that we know reality, a reality partly but not wholly constituted by us. There is always a givenness not constructed by any individual or cultural group. Except in the case of other experients (and unless one accepts a panpsychic viewpoint without remainder, which I earlier rejected as an expression of modern idealism), the given element is not itself already fully constituted or definite, not a "world" apart from our participation, but open to our fuller definition. From a postmodern perspective, it is neither necessary nor plausible to postulate either a concrete, complete physical realm or a reified moral order completely independent of a world evolving and under construction. But neither is the given simply indefinite or amorphous. Certainly no one can directly or concretely describe the given, for any description involves our constituting activity. Here we can helpfully contrast the moderate postmodern vision with other options. While radical postmodernism denies any world beyond our constituting activity and Kantian modernism postulates a fully constituted world independent of, but partially accessible through, our constituting activity, moderate postmodernism sees given elements and our constituting activity as together forming the world.

Because of the uncompromising commitment that we are embodied in reality, con both radicals and postliberals, moderates reject any strong doctrine of incommensurability and credit others with some grasp of truth. Even radically divergent perspectives may at some level apprehend the same given element of reality. Moderate postmodernism holds that error is corrigible—not by some absolutely privileged, infallible, inherently different method, but by our normal ways of coming to know in the world; that there are better and worse; that in moving from one perspective to another, we 
not only achieve something aesthetically novel (as in Lyotard’s “paralogy”), but can stretch to fuller truth. In short, moderate postmodernism places us in the muck and mire of real existence with all its ambiguity, where none of us has any absolute possession of the truth but none of us is totally blind either, where we may be "often perplexed, but not defeated,” where we can and should reach for fuller truth and greater value.

With the radicals, moderates recognize that part of Christianity's largest context of meaning involves its interconnections with differing worldviews. While maintaining Christianity's relative identity, it eschews the notion of Christianity’s absolute difference from other religions and worldviews. It willingly and hopefully enters into dialogue with the other. While acknowledging that a Western Christian cannot know Buddhism, for example, precisely as someone enculturated in Buddhism from birth, it believes that mutual translation and understanding are possible. It shares its viewpoints and commitments in the faith that they (and those of the partner in dialogue) can have relevance to more than an isolated context, can have more universal meaning. Change and even conversion are possible outcomes of dialogue. Such faith involves the basic assumption that continuous with our rootedness in a particular culture and tradition is our rootedness in the being/becoming of the world.

The moderate branch recognizes our immanence in contexts of meaning in a way that modernity did not and disavows its assumption or standard of absolute transcendence. But unlike the other two branches, it does allow a significant place for freedom and transcendence, as the preceding analysis suggests. Humans have the potential and sometimes the obligation to critique smaller and larger contexts of meaning and to embrace or reject them, the potential to change our judgments regarding truth and 
our moral commitments. The middle branch alone consistently gives the critical side of the postmodern spirit its due.

As does radical postmodernism, the moderates image humanity and divinity harmoniously. As some balance of transcendence and immanence pertains to humans, so too to God. A stronger sense of divine immanence prevails than in classical theology, even as greater immanence characterizes its portrait of humanity. To the extent they address directly concepts or metaphors for God, postmodern moderates may favor panentheism, as do Protestants Sally McFague and Peter Hodgson and Catholic David Tracy.

\section{Epilogue}

A sense of rootlessness and of the arbitrariness of ways of life has grown in Western civilization over the past century or more. This rootlessness and disembodiment derives in part from the controlling picture of modernity, a picture that denies our roots. Modernity initially hoped that critical reason would banish the arbitrariness of individual and institutional beliefs and practices. As reason failed to establish absolute truth, hopes for overcoming arbitrariness increasingly banked on the prereflective; however, this hope was dashed as well. The past century also saw an increasing awareness of alternative cultures and worldviews.

While preliminarily acknowledging bodily and social rootedness, radical postmodernists, like some existentialist forerunners, applaud rootlessness and arbitrariness-relativism. The desire to feel "at home” in the world, for things to "hang together,” is finally inappropriate and unhealthy. Postliberals by contrast attempt to 
purchase at-home-ness by positing an absolute grounding in a tradition. Given an increasing sense of uprootedness in modern and postmodern worlds, it should not surprise us that both radical celebration and postliberal exorcism of rootlessness and arbitrariness have appeal.

Refusing either extreme, moderate postmodernism acknowledges both our rootedness in meaning — through our bodies and traditions I would claim—and the element of arbitrariness in all ours ways of viewing and doing. Nothing is absolute or necessary in a logical sense, yet this does not preclude meaning and coherence. Our rootedness in our bodies and world is not one of stasis, but of openness both to new constitutions of the world and to fuller apprehensions of the world's givenness.

The postmodern insight that everyone must stand somewhere can be startling. Radical and conservative postmodernism see everyone as standing irreconcilably far apart. The radicals, though, attempt to overcome such incommensurability by the standing everywhere-nowhere of endorsing equally every position. Moderate postmodernism recognizes our differences, but affirms that through our embodiment in the world we do not stand irreducibly far apart.

The abandonment of the modern assumption of and search for the privileged position of absolute self-possession, absolute transcendence with respect to time, and absolute clarity and certainty, will sadden some. But perhaps renouncing any absolute human perspective should not be that unsettling. Those who disbelieve in God presumably have no reason to expect any absolute perspective. Those who believe in God might well confess that there is only one absolute perspective, and that it belongs to God. 


\section{ENDNOTES}

1'Postmodern' has gained supremacy over the alternative terms 'postcritical' and 'postliberal'. Michael Polanyi's 'postcritical' stands as probably the best single word for conveying the substance of the shift from modernity as I construe it in this essay. The term, as I understand it, does not suggest the impossibility or undesirability of appropriate critical reflection, but rather modernity's failure to recognize the limits of critical reasoning. 'Postliberal' does connect with 'postcritical' insofar as one of those limits is the impossibility of (and the wrong-headedness of attempting) totally to transcend tradition. However, one cannot answer the question of how far one can or should transcend tradition in a particular cultural or religious context with generalities. It should not surprise us then that 'postliberal' is the term of choice for those with a conservative orientation.

${ }^{2}$ I am indebted to my mentor in postmodernity, William H. Poteat, for the concept of the controlling "picture," as well as for the idea, developed later in this essay, that idealism and empiricism represent flip sides of the same dualistic coin. (Poteat in turn was influenced by French phenomenologist Maurice Merleau-Ponty on this latter idea.)

${ }^{3}$ In this essay I use the term "critical reason” in a general sense, meaning reason as it questions and/or attempts to establish or justify or make explicit meaning and value.

${ }^{4}$ Martin Luther, taking a much more critical stance toward Scripture than subsequent Protestant scholastics, foreshadowed critical activities of the Enlightenment by denying the historical accuracy of parts of the Bible and by judging as theologically invalid certain biblical books (Van A. Harvey).

${ }^{5}$ Though certainly both positive and negative practical and social consequences have issued as well. For example, on the positive side: 1) many accomplishments of science, medicine, and technology 2) the overthrowing of many superstitions 3 ) a sense of universal human rights; on the negative side: 1) the exploitation of nature and ecological crisis 2) the common practice by physicians of treating patents as just physical organisms (a practice that many medical schools now discourage in something of a postmodern trend). Given my contention that postmodernity corrects excesses of modernity and is impelled by a more truthful controlling assumption, a reader might get the impression that I regard modernity as "bad" and postmodernity as "good." As my preceding remarks suggest, such simplism does not represent my overall position.

${ }^{6}$ While Kant came to deny that we can know any "thing in itself," as he grappled with the implications of modernity's subject-object split, what is noteworthy is his very assumption of a fully determinate object in itself, albeit unknowable, behind any perception.

${ }^{7}$ Note that my wording entails that, in knowing, something is there---something "stands against" us. Postmodernity's logic does not permit the subjectivistic and solipsistic tendencies of modernity. We, individually or collectively, only partly create the world we know. The correspondence theory of truth is not altogether wrong.

${ }^{8}$ Polanyi’s term "postcritical," consonant with what I am calling "the postmodern spirit," takes in both the critical and the acritical or precritical. Polanyi assented to-critically- "the greatly increased powers of man,” granting us a "capacity for self-transcendence of which we can never again divest ourselves.” (PK, 268).

${ }^{9}$ It is no coincidence that David Ray Griffin typically identifies modernity and its negativities with its materialistic and sensationalistic side, while largely overlooking its idealist side.

${ }^{10}$ For a related evaluation, see David E. Klemm. 


\footnotetext{
${ }^{11}$ Though radical pragmatism-historicism has affinities with poststructuralism, it has not been as influential among theologians.

${ }^{12}$ Though it may well be that deconstruction's reliance on reflective and linguistic metaphors for realitysuch as, "writing," "text," "interpretation"- -hinders it from acknowledging our (more) prereflective and bodily grounding in meaning.

${ }^{13}$ By “meaning,” I connote both sense and value.

${ }^{14}$ I believe Sallie McFague granted deconstruction too much in Models of God, in writing that "absence is at least more prevalent than presence" (25). This conflicts, or at least is in tension, with her assumption that Christian faith is "most basically a claim that the universe is neither indifferent nor malevolent but that there is a power (and a personal power at that) which is on the side of life and its fulfillment" (x).

${ }^{15}$ By “absolute," I do not mean to suggest that God is unrelated to or unaffected by creation.

${ }^{16}$ Charles W. Allen describes tribalism’s threat-irrelevancy polarity in “The Primacy of Phronesis.”

${ }^{17}$ See Dale Cannon, David W. Rutledge, and Esther L. Meek, Tradition and Discovery 31/3, for additional discussion of Meek's theology relative to Polanyi's post-critical philosophy
}

\section{REFERENCES}

Allen, Charles W. 1989 “The Primacy of Phronesis: A Proposal for Avoiding Frustrating Tendencies in Our Conception of Rationality.” Journal of Religion 69:359-74.

Beardslee, William, 1989 Varieties of Postmodern Theology. Albany: State David Ray Griffin University of New York Press. and Joe Holland
Cannon, Dale
2005 "Longing to Know If Our Knowing Really Is Knowing." Tradition and Discovery 31/3:6-20.
Caputo, John D.
1997 The Prayers and Tears of Jacques Derrida: Religion without Religion. Bloomington: Indiana University Press.
Derrida, Jacques
1978 Writing and Difference. Chicago: University of Chicago Press.

1994 Specters of Marx. Trans. by Peggy Kamuf. New York: Routledge. 
Harvey, Van A. 1964 A Handbook of Theological Terms. New York: Macmillan. S. v., "Inspiration of the Bible."

Hauerwas, Stanley 1985 Against the Nations: War and Survival in a Liberal Society. Minneapolis: Winston Press.

1988 Christian Existence Today: Essays on Church, World, and Living in Between. Durham, NC: Labyrinth Press.

Hodgson, Peter C. 1989 God in History: Shapes of Freedom. Nashville: Abingdon Press.

Hopper, Jeffery. 1987 Understanding Modern Theology II: Reinterpreting the Christian Faith for Changing Worlds. Philadelphia: Fortress Press.

Klemm, David E. 1987 “Toward a Rhetoric of Postmodern Theology: Through Barth and Heidegger." Journal of the American Academy of Religion 15:457-66.

Leahy, D. G.

1980 Novitas Mundi: Perception of the History of Being. New York: New York University Press.

1989 “To Create the Absolute Edge.” With an introduction by Thomas J. J. Altizer. Journal of the American Academy of Religion 17:773-89.

Lindbeck, George 1984 The Nature of Doctrine: Religion and Theology in a Postliberal Age. Philadelphia: Westminster Press.

Lyotard, Jean-Francois

The Post-Modern Condition: A Report on Knowledge.

1984 Trans. by Geoff Bennington and Brian Massumi with a foreword by Fredric Jameson. Minneapolis: University of Minnesota Press.

McFague, Sallie 1987 Models of God. Philadelphia: Fortress Press.

Meek, Esther L. 2003 Longing to Know: The Philosophy of Knowledge for Ordinary People. Grand Rapids, MI: Brazos Press.

2005 "Longing to Know and the Complexities of Knowing God." Tradition and Discovery 31/3:29-43. 


\footnotetext{
Merleau-Ponty, Maurice Phenomenology of Perception. Trans. by Colin Smith.

1962 London: Routledge and Kegan Paul.

Milbank, John et al. 1999 Editors. Radical Orthodoxy: A New Theology. London: Routledge.

Moore, Stephen D. 1989 The 'Post-'Age Stamp: Does It Stick-Biblical Studies and the Postmodernism Debate." Journal of the American Academy of Religion 17:544-49.

Neuhaus, John Richard The Catholic Moment: The Paradox of the Church in the 1987 Postmodern World. San Francisco: Harper \& Row.

Polanyi, Michael 1958 Personal Knowledge: Towards a Post-Critical Philosophy. Chicago: University of Chicago Press.

Poteat, William H. 1985 Polanyian Meditations: In Search of a Post-Critical Logic. Durham, NC: Duke University Press.

Raschke, Karl $\quad 1990$ Fire and Roses: Toward Authentic Post-Modern Religious Thinking." Journal of the American Academy of Religion 18:675-76.

Rutledge, David W. 2005 "Knowing as Unlocking the World: A Review Essay on E. L. Meek’s Longing to Know.” Tradition and Discovery 31/3:21-28.

Rutler, George William Beyond Modernity: Reflections of a Post-Modern Catholic. 1987 San Francisco: Ignatius Press.

Taylor, Mark C. 1984 Erring: A Postmodern A/theology. Chicago: University of Chicago Press.

1991 “The Politics of Theo-ry." Journal of the American Academy of Religion 19:1-37.

Tracy, David

1987 Plurarity and Ambiguity: Hermeneutics, Religion, Hope. San Francisco: Harper \& Row.

1994 "Literary Theory and Return of the Forms for Naming and Thinking God. Journal of Religion 74:302-19.

Wall, James A. 1986 "Meaning, Mystery, and Modernity.” Lecture at the Futures Forum, United Methodist Publishing House. (On cassette, Newscope Lecture Series, June, 1987.)
} 
Winquist, Charles 1986 Epiphanies of Darkness: Deconstruction in Theology. Philadelphia: Fortress Press.

Wittgenstein, Ludwig 1958 Philosophical Investigations. $3^{\text {rd }}$ edition. Trans. by G.E.M. Anscombe. New York: Macmillan

Yoder, John Howard 1984 The Priestly Kingdom: Social Ethics as Gospel. Notre Dame, IN: University of Notre Dame Press. 